\title{
A taste of his own medicine: analyzing Émile Zola's interpretation of Claude Bernard's experimental method
}

\author{
Pascale Rabideau* \\ *This manuscript was prepared under the supervision of Professor Margot Irvine, \\ School of Languages and Literatures, College of Arts, \\ University of Guelph, Guelph, Ontario, Canada
}

\begin{abstract}
In 1880, Emile Zola (1840-1902) wrote Le Roman Expérimental. He believed that with the application of the scientific method, fictional novel writing could be a scientific field used to study human passions and psychology. Zola claims to take his method and arguments directly from French physiologist Claude Bernard's (1813-1878) Introduction à la l'étude de médecine expérimentale (1865). But did Zola really understand Bernard's experimental method? Comparing the experimental method outlined in Zola's essay and Bernard's book, it becomes apparent that although Zola understood the steps involved in Bernard's method, his application of it to literature is flawed. He takes quotations out of context, he assigns contradictory values to the scientific validity of the experimental novel, and most fatally, Zola's version of an experiment comes nowhere close to being what Bernard would consider a true scientific experiment.
\end{abstract}

$\mathrm{D}^{\mathrm{u}}$ uring the nineteenth century in Europe, an increased interest in scientific progress began to sweep intellectual and social circles. This interest was not only isolated to scientific circles, but infiltrated into literature as well. A very interesting example of this relationship emerged in France during the late nineteenth century. A fury of scientific activity and technological development had been changing the face and mindset of Europe during the past two centuries - by the end of the seventeenth century, the bases of scientific methodology and experimentation had already been developed. But despite these changes, by the middle of the nineteenth century, medicine was still struggling to be considered as an experimental science. In 1865, French physiologist Claude Bernard (1813-1878) published Introduction à l'étude de la médecine expérimentale (Introduction to the Study of Experimental Medicine), outlining the core of the scientific experimental method as it could be applied in medicine. Now considered a classic scientific text, Bernard's book helped change perceptions and helped medicine evolve into being accepted as an experimental science. A short decade after Bernard's death, French naturalist writer Émile Zola (1840-1902) reprised Bernard's work in an essay entitled Le Roman Expérimental (1880). In it, Zola sought to prove that Bernard's experimental method could be applied to literature in order to make novel writing a scientific domain as well. While Zola seemed have a genuine interest in sciences and seemed to understand Bernard's arguments, his application of the experimental method to writing contains fundamental flaws. There are instances where Zola takes Bernard's quotations out of context in order to support an unrelated argument. Zola also ascribed contradictory roles to the experimental novel, undermining its "scientific validity", and more problematically, Zola's version of an experiment does not conform to Bernard's description of a valid scientific experiment.

\section{HISTORY AND INTENT OF BERNARD'S “ INTRODUCTION TO THE STUDY OF EXPERIMENTAL MEDICINE”}

\section{History}

As a young man, Bernard set out to begin a career in literature, but quickly found his calling in medicine. He interned at the Hotel Dieu in Paris and studied under the famous physiologist François Magendie. It was during this time that Bernard was introduced to the concept of experimentation in medicine. Through the use of experimentation, in twenty years, Bernard had made arguably more important advances in physiology than any of his contemporaries [1]. His most famous discoveries include the functions of several glands (most notably the pancreas), the existence of vasomotor nerves, and the glycogenic function of the liver. During Bernard's time, chemistry, physics, and mathematics were considered pure sciences, 
each with the application of a scientific experimental method. Medicine, however, was still considered an art by many in France. With the experimental method and a clear set of laws, predictable and repeatable results could be yielded in the pure sciences. In medicine, however, there seemed to be no set laws or method. The same treatment could be applied to two patients with the same problem and yield opposite results. Physicians were often hailed as 'artists' because they were credited with using a personal method and intuition in treatment as opposed to a standard scientific method. Another barrier for medicine was a continuation of vitalistic ideas in the practice. Since ancient times, the philosophical theory of vitalism had permeated medicine. It claims that living beings have an inherent 'life force' which made them different from inanimate objects. As such, the laws governing pure sciences were perceived as having no place in science. In his book, Bernard argues vehemently against vitalism and personal methods in medicine. For Bernard, the experimental method is the only way to advance medicine.

While Bernard clearly rejects vitalism, one philosophic movement he embraces is positivism. Pioneered by French sociologist Auguste Comte (1798-1857), positivism was a theory that claimed that mankind has progressed through three stages (theological, metaphysical and positive). Humanity evolved from using supernatural explanations to using scientific reasoning to explain natural phenomena [2]. Comte's theory had an important impact on the French intellectual and scientific culture during the nineteenth century - Bernard and Zola were no exceptions. Bernard emulates positivism in his philosophy of the sciences [3]. He states that in order to obtain truth, sciences must use experimentation in order to determine the causes and workings of nature:

Men of science learn every day from experience; by experience they constantly correct their scientific ideas, their theories; rectify them, bring them into harmony with more and more facts, and so come nearer and nearer to the truth. - Bernard, Introduction. 1957. $\mathrm{Pg} 12{ }^{\mathrm{i}}$

Medicine, like any other science, shares the goal of discovering truths about the physical world.

\section{Why Write An Introduction to the Study of Experimental Medicine?}

Bernard wrote An Introduction to the Study of Experimental Medicine as a response to vitalism and to those claiming that medicine could not be considered an experimental science. The book focuses on two main points, that the experimental method is common to all experimental sciences and that it can be applied to medicine. In the first section of the book, Bernard describes experimental reasoning in its method as well as in its importance to science. In the rest of the book he argues that the experimental method already existed for chemistry and physics and that it can be applied to medicine (physiology, pathology, and therapeutics) [4]. Bernard argues that the same laws that act on inanimate objects also act upon and within living bodies, and that the experimental method is the only way to discover those interactions:

\begin{abstract}
It is therefore clear to all unprejudiced minds that medicine is turning toward its permanent scientific path. By the very nature of its evolutionary advance, it is little by little abandoning the region of systems, to assume a more and more analytic form, and thus gradually to join in the method of investigation common to the experimental sciences. - Bernard, Introduction. 1957. Pg 1. ${ }^{\text {ii }}$
\end{abstract}

Medicine's evolution towards becoming an experimental science is inevitable. According to Bernard, deduction by observation alone in medicine led to error in theories, treatments, and a lack of universal progress in the field. A lack of experimental reasoning and method led to the acceptance of vitalistic beliefs and was, in his opinion, a huge obstacle for science [5].

There are many details and issues covered in Introduction, but for the purposes of this article the focus will be on the first section of the book, which outlines Bernard's experimental method, its role and its importance in medicine and society. This is the section from which Zola takes most of the quotations used in The Experimental Novel.

\section{History AND INTENT OF ÉMILE ZoLA's “ThE EXPERIMENTAL NOVEL"}

\section{History}

Zola (1840-1902) was a journalist and novelist whose career spanned the latter half of the nineteenth century. He is considered the founder of the short-lived French naturalist movement. Naturalism extended from the French realist movement pioneered by Honoré de Balzac (1799-1850) and Gustave Flaubert (1821-1880). Realism was a reaction against romanticism from earlier in the nineteenth century. The importance of emotion and the supernatural in romanticism was replaced with logic and the rational. Realism was based on the observation of society, description and history [6]. What sets naturalism apart from realism is its purpose and its level of detail. While realism sought to create a picture of reality, naturalism sought to understand it. Zola would spend months in preparation for writing, taking detailed notes about specific historical events, settings, and people's behaviours. He wanted his novels to be more than realistic, he wanted them to be an analysis of social and genetic histories, conducted by his own ideas of scientific experimentation.

Throughout his life, Zola showed an interest in science. He was well-versed in the natural selection theories of Charles Darwin (1809-1882), the theories on heredity of 
Prosper Lucas (1805-1885), and almost as importantly, the experimental method of Claude Bernard [7]. It was Bernard's Introduction which fascinated and inspired Zola to apply his own 'experimental method' to literature. He wanted to do more than just conduct a social study of society as the realists had done. Carried along by the positivist wave in society, Zola wanted literature to become a scientific endeavour in itself.

\section{Why Write Le Roman Expérimental?}

Zola's essay is written with a specific agenda. He sets out to prove three main points. First and foremost, Zola sets out to prove that Bernard's experimental method could be directly applied to literature:

I am going to try to prove for my part that if the experimental method leads to the knowledge of physical life, it should also lead to the knowledge of the passionate and intellectual life. It is but a question of degree in the same path which runs from chemistry to physiology, then from physiology to anthropology and to sociology. The experimental novel is the goal. Zola, The Experimental Novel. $\mathrm{Pg} 1$ 1.ii $^{\text {ii }}$

Zola applies Bernard's arguments to literature, trying to dispel criticism for his 'scientific approach' and to prove that it is natural for literature to evolve into its own experimental science.

Secondly, Zola seeks to distinguish naturalism from realism and romanticism by use of experimental method. While Zola was heavily influenced by realist authors, he also sought to 'out do' these literary giants by claiming the prestige of scientific activity in his writing [8]. Zola claimed that he could use the method to uncover truths about human society. It would then be used to work towards human betterment and happiness. Unlike the realists, who sought to document society, he wanted his novels to be "...scientific, a series of experiments constructed by a new type of scientist working with pen and ink, instead of test tubes and a Bunsen burner [9]."

Thirdly, Zola sought to dispel critique from those calling his work immoral. His earlier works, La Confession de Claude (1865) and Thérèse Raquin (1867) included strong themes of adultery, political corruption and criticism, degenerative genetics diseases and murder. Although met with public outcry and strong criticism, the controversial themes actually served to increase publicity and sales. Although Zola probably believed in the concept of the experimental novel to a large degree, explaining the necessity of a scientific value and objective tone to his writing was a way of escaping moral condemnation. He claimed that he was not personally condoning the actions of the characters, but rather participating in a scientific experiment of the highest moral importance for society. Regardless of which of the three reasons was his main objective, one must first understand Bernard's experimental method in order to understand Zola's application of it.

\section{Bernard's Experimental Method}

Bernard believed that all sciences have the same goal: to "try to reach knowledge of the law of the phenomena, as to foresee, vary or master phenomena" [10]. ${ }^{\text {iv }}$ It is not enough for sciences to be able to predict the occurrence of phenomenon, they explore them so as to understand how they are caused and how they can be manipulated and controlled.

\section{THE DifFERENCE BETWEEN OBSERVATIONAL AND EXPERIEMENTAL SCIENCE: THE ROLE OF OBSERVATION AND EXPERIMENTATION}

First, Bernard explains the difference between observation and experimentation and the difference between observational and experimental science. He explains that observation is simply watching, analysing and recording how things in nature present themselves. Experimentation involves manipulating the object to put it into specific conditions in order to test an idea [11]. Bernard argues that experimentation is necessary to a true science:

\begin{abstract}
By simply noting facts, we can never succeed in establishing a science. Pile up facts or observations as we may, we shall be none the wiser. To learn, we must necessarily reason about what we have observed, compare the facts and judge them by other facts used as controls. - Bernard, Introduction. 1957. Pg 16. ${ }^{\vee}$
\end{abstract}

While it is possible to create theories or obtain a better understanding of nature through observation, Bernard argues that without experimentation, there is no way of verifying these theories and hypotheses. Without experimentation, there is too much room for error and misinterpretation of the causes of phenomena. He cites astronomy as an example of an observational science - theories concerning the movement of the celestial bodies must be drawn from observation alone, for there is no way of acting on the bodies in order to test the theories. Chemistry is cited as an example of an experimental science because a chemist creates specific conditions and experiments to act upon compounds and molecules in order to discover their properties and the laws governing them.

\section{The Experimental Method}

Bernard argues that the purpose of experimental medicine is to determine the laws of physiological and biological phenomenon in order to predict, manipulate, and control them with the eventual goal of mastering and curing all disease. In order to attain this goal, it must adopt the experimental method common to physics and chemistry. He outlines three stages - observation, experiment, and conclusion: 
In all experimental knowledge, indeed, there are three phases: an observation made, a comparison established and a judgment rendered. By the experimental method, we simply make a judgment on the facts around us, by help of a criterion which is itself just another fact so arranged as to control the judgment and to afford experience. - Bernard, Introduction. 1957. $\mathrm{Pg} 12-13 .^{\mathrm{vi}}$

From the initial observation, an idea arises that can be tested. The physician then creates and conducts an experiment in order to test the hypothesis, and can either confirm or disprove the original idea based on the results of the experiment.

\section{1) Observation}

All experimental hypotheses arise out of observation. As a physician studies a phenomenon as it presents itself in nature, and in the context of previous research on the subject, an idea about its cause arises [12]. Bernard states the importance of the initial observation:

Following an observation, an idea connected with the cause of the observed phenomenon presents itself to the mind. We then inject this anticipative idea into a train of reasoning, by virtue of which we make experiments to control it. - Bernard, Introduction. 1957. $P g$ 33. ${ }^{\text {vi }}$

The observation resulting out of the first stage is the foundation for the experiment phase.

\section{2) Experiment}

A physical experiment must be constructed and conducted in order to test the idea. Bernard explains:

In the experimental method, search for facts, ie, investigation, is always accompanied by reasoning, so that experimenters usually make an experiment to control or verify the value of an experimental idea. Bernard, Introduction. 1957. Pg 19. viii

A good experiment will be able to support or disprove a hypothesis. In order to test it, there are two fundamental elements required- a well-thought out experiment and the proper tools to conduct and record the results of the experiment. The experimenter must properly define the parameters, tools, and conditions under which the experiment occurred to ensure that if replicated, the experiment's results can accurately be compared [13].

Another important aspect to the experiment phase is impartiality:

The experimenter must now disappear or rather change himself instantly into an observer; and it is only after he has noted the results of the experiment exactly [...] that his mind will come back, to reason, compare and decide whether his experimental hypothesis is verified or disproved by these very results. - Bernard, Introduction. 1957. $\mathrm{Pg} 22 .{ }^{\text {ix }}$

As the experiment is conducted, the experimenter must become an observer and only analyse and interpret the results once they are recorded in an unbiased manner.

\section{3) Results and Conclusions}

During the third stage, the scientist compares the original observations with results from the experiment in order to verify and judge the hypothesis. There are two possible outcomes: i) the experiment supports the hypothesis, it is considered as evidence towards confirming the theory concerning the cause of the phenomenon; or ii) the experiment contradicts the hypothesis.

If it contradicts the hypothesis, Bernard argues that the hypothesis should not automatically be discarded, but rather that first the entire experiment should be analysed to see if the experiment itself was the source of error (in method, tools, or reasoning). It is only in continually testing and reconstructing our understanding of nature that science will advance closer to 'truth'.

\section{Importance and Application of the Method}

Bernard argues that the experimental method is the only way to advance science towards knowing truths about nature and the universe. Even if the experiments on complicated subjects fail to prove a hypothesis, they can generate new ideas for future experiments or hypotheses. Bernard refers to these types of experiments as "experiments to see" [14]. ${ }^{\mathrm{x}}$ The next researcher may use the previous experiment to make a breakthrough on the subject. Bernard views science as a collaborative activity where all scientists labour together, building off one another's work in order to come closer to truth. The individual genius of the scientist is in their ability to reason experimentally, create experimental conditions, and interpret results to test their hypotheses. In the latter half of his book, Bernard supports his arguments using examples from his own personal research and experience as a physiologist, professor, and researcher. In conclusion, he addresses criticisms of his method and restates the inevitability of medicine becoming an experimental science alongside physics and chemistry. He restates his argument that if the experimental method is applied in medicine, it will serve to standardize the practice (by removing personal classification systems and folk superstitions) and evolve medicine towards a complete understanding of physiology, pathology, and therapy in order to successfully treat and prevent disease.

\section{Zola's Experimental Method}

Zola insists that the experimental method as outlined by Bernard in the Introduction is directly applicable to literature in the form of the naturalist experimental novel. He claims 
that Bernard's arguments advocating the use of the method in medicine are one and the same for its use in literature:

I really only need to adapt, for the experimental method has been established with strength and marvellous clearness by Claude Bernard in his "Introduction à l'Étude de la Medicine Expérimentale". This work [...] will serve me as a solid foundation. [...] This will then be but a compiling of texts, as I intend on all points to entrench myself behind Claude Bernard. It will often be but necessary for me to replace the word "doctor" with "novelist," to make my meaning clear and to give it the rigidity of a scientific truth. - Zola, The Experimental Novel. 1964. pg $9 .{ }^{\mathrm{xi}}$

During the first part of his essay, Zola summarises the purpose and core arguments of Introduction. He then explains how Bernard's method can be applied to the novel. Bernard expresses a firm belief in determinism - that all aspects of life are regulated by determined laws. He argues that even in its complexity, the workings of the human body are determined by set physical and chemical laws. Zola uses that point as a springboard into his argument for the experimental novel:

\begin{abstract}
...and since savants like Claude Bernard demonstrate now that fixed laws govern the human body, we can easily proclaim, without the fear of being mistaken, the hour in which the laws of thought and passion will be formulated in their turn. A like determinism will govern the stones of the roadway and the brain of man. - Zola, Le The Experimental Novel. 1964. Pg 9. ${ }^{\text {xii }}$
\end{abstract}

Zola agrees with Bernard that all phenomena are dictated by determined laws and extrapolates from the statement to include human psychology and brain activity. Zola claims that the experimental novel will be one way to discover causes of psychological and emotional phenomena. Just as Bernard states that medicine is still considered an art and is in its infancy as an experimental science, so Zola claims that the experimental novel is also in its infancy. He also claims that a combination of heredity and social environment influence and determine emotions and social phenomena. The results of the 'experiments' are supposed to provide law makers and sociologists with tools and understanding to create laws and set moral standards accordingly. Zola takes Bernard's three phases of the experimental method and applies them to the novel.

\section{1) Observation}

The experimental novelist observes society and individuals. Like the scientist, as he studies society, a hypothesis arises which must be tested. In preparation for the experiment, the novelist observes and studies geographical locations (depending on where the novel is going to be set), individuals in different social classes and professions, politics, religion, history, and all scientific research concerning the issue in question. An experimental novel usually sets out to explore a specific issue (ie the inheritance of alcoholism as in L'Assommoir) [15]. From the novelist's observations arises the idea that they will test in their experiment - the novel.

\section{2) Experiment}

The experiment for an experimental novelist is the novel itself. The experimental novelist creates characters with specific characteristics and places them in 'experimental conditions' in order to test their hypothesis. The experiment is supposed to arise from the interaction of specific hereditary attributes, social class, and the interaction of specifically created characters.

Then the experimentalist appears and introduces an experiment, that is to say, sets his characters going in a certain story so as to show that the succession of facts will be such as the requirements of the determinism of the phenomena under examination call for. - Zola, The Experimental Novel. 1964. Pg 5. ${ }^{\text {xiii }}$

Just as Bernard claims that the genius of the individual scientist is in their capacity to reason and create experimental conditions to test their hypotheses, so Zola claims that the genius of the novelist is in their creative ability to create characters and conditions that will effectively verify their hypothesis [16]. For the author, the experiment is within the nature of the characters, and in the conditions and the situations through which they live.

\section{3) Results and Conclusions}

The actions, emotions and physical states of the characters throughout and at the end of the novel are the 'results' of the experiment. Once the novel is completed, the experimental novelist then compares their original observations with the 'results' of the novel in order to render a judgement on their hypothesis:

He set out from doubt to reach positive knowledge; and he will not cease to doubt until the mechanism of the passion, taken to pieces and set up again by him, acts according to the fixed laws of nature. There is no greater, no more magnificent work for the human mind. - Zola, The Experimental Novel. 1964. Pg 7. ${ }^{\text {iv }}$

Zola echoes Bernard's value of objectivity and the role of doubt in experimentation. The experimental must compare the initial idea with the end results with objectivity to reveal truths about human nature as to better the human condition with the new understanding.

Zola, unlike Bernard, claims that the interpretation of results and evaluation of the hypothesis does not necessarily 
have to be conducted by the experimental novelist themselves, but rather that it is society's role:

I have often said that we do not have to draw a conclusion from our works; and this means that our works carry their conclusion with them. An experimentalist has no need to conclude, because, in truth, the experiment concludes for him. [...] It is for society to produce or not produce these phenomena, according as the result is useful or dangerous. - Zola, The Experimental Novel. 1964. Pg 17. ${ }^{\mathrm{xv}}$

In Bernard's method, the hypothesis, the experiment and results are created and analysed by the same scientist. Zola claims that the experimental novelists' results are so obvious that they speak for themselves and that it is society's responsibility to interpret the results and use the new understanding to improve. An obvious challenge to this claim is the wide spectrum of reactions to and interpretations of Zola's novels themselves. If so many people reacted adversely to his novels that Zola had to write two manifestos explaining his intent and method (Preface to the $2^{\text {nd }}$ edition of Thérèse Raquin and The Experimental Novel), then surely the original observations to compare the results and, moreover, the fact that he was conducting an experiment at all could not have been as clear and obvious as he claims.

\section{Importance and Role of the Experimental Novel}

Zola claims that the experimental novel discovers laws ruling over human psychology, thereby giving law makers and society greater insight into how to prevent crime and immorality.

Unlike Bernard, who gives specific examples of how he applied the experimental method in his own research and how the resulting conclusions changed actual theories in the field of physiology, Zola provides no specific examples or applications resulting from an experimental novel. He cites Balzac's Cousine Bette as an example of an early experimental novel, but provides resulting conclusions on neither human relations nor any evidence that it changed French society. Overall, the application of the results of the experimental novel is fairly vague and is the least explained of the three stages.

\section{Critique of Zola's Method}

While Zola does a fairly accurate job of summarising the main points of Bernard's Introduction, there are a few serious flaws in his application of the experimental method in literature. Zola takes quotations out of context in order to use them to support completely unrelated arguments. In so doing, he undermines the validity and importance of the experimental novel; and most fatally, Zola's version of the experiment stage comes nowhere close to being what Bernard would consider a true scientific experiment. The clearest example of Zola quoting Bernard out of context comes early on in his essay. When Bernard writes that experimentation needs to be practiced in hospitals, amphitheatres and laboratories [17], Zola interprets this as proof that the experimental method will be one day practiced in all levels in society - including literature. What Zola does not explain is that in that specific quotation, Bernard refers specifically to experimentation in all forms of medicine, and in all places were medicine is practiced. Later on in Introduction, Bernard explains the passage in depth. He explains that the experimental method and reasoning should be taught to young physicians in school ("amphithéâtres"), used for observation in hospitals, and conducted in experiments in laboratories. It has nothing to do with the average lay person and is especially not directed towards novelists.

In the first half of his essay, Zola claims that the experimental novel will be used to arrive at absolute scientific principles [18]. This claim is undermined in other parts of the essay, where Zola claims that the experimental novel is more of an "experiment to see" [19] - an attempt to generate ideas for a scientists' research. Near the very end of the essay, Zola compares the role of the experimental novelist to that of the philosopher, as described by Bernard. Bernard distinguished between sciences - which seek the how of how things work - and philosophy, which seeks the why. Bernard argues that while philosophy can never arrive at a conclusion about truth, its role is to inspire and guide the sciences:

By ceaselessly stirring the inexhaustible mass of unsolved questions, philosophy stimulates and maintains this healthful movement in science. For the indeterminate belongs to philosophy, [...] while the determinate necessarily falls into the realm of science. - Bernard, Introduction. 1957. Pg 223. ${ }^{\mathrm{xi}}$

Zola claims that experimental novelists serve the same role as philosophers - to generate ideas and inspiration for scientists. The problem is that Bernard explicitly states that philosophers themselves can never uncover scientific truths. In making that comparison, as with his claims to being an experiment to see, Zola undermines his original argument that the experimental novel is a valid and necessary scientific enterprise.

The fundamental flaw with Zola's theory, however, is that his version of an experiment does not conform to Bernard's standards of a scientific experiment. If we recall Bernard's explanation of observation and experimentation, observation is merely forming conclusions based upon seen phenomena naturally occurring in nature. Experimentation is verifying a hypothesis based upon a comparison between an original observation from nature and a second observation resulting from a manipulated experiment. In a theoretical sense, Zola is taking an original observation and comparing it to the results of an experiment (based on character interaction in the novel), but the problem is that it is an entirely fictional experiment. There are no real people being 
acted upon and no physical results. Bernard himself undermines Zola's entire argument by saying that "the mind in itself has only the feeling of a necessary relation between things: it can know the form of that relation only by experience" [20]. ${ }^{\text {xii }}$

Zola's experiments are entirely based on the relations he perceives between things. Because there is no physical experiment, the 'results' he records are completely fictional. Zola claims scientific accuracy and objectivity. In an experimental novel, however, the results are either deducted from the hypothesis or completely created from the author's imagination. Perhaps there would be some interest in physically conducting Zola's experiments and studies on actual people, but that would enter the domain of psychology or anthropology, and would no longer be fictional literature. Either way, the conclusions drawn from such an experiment have no scientific or truly objective value. This last criticism of Zola's theory is by no means new. In the same year that Zola published The Experimental Novel, literary critic Ferdinand Brunetière published a scathing review of Zola's essay, in which he outlined the same fundamental problem:

It is obvious that Mr. Zola does not know the meaning of experimentation, because a novelist is like a poet if he experiments, he can only experiment on himself, not on others [...] there is no, nor can there be, experimentation, there is only observation, and that is enough to make Mr. Zola's theory in the Experimental Novel to be lacking, and thus collapse from the foundation up [21]. - Brunetière. Le Revue des deux mondes. 15 février 1880. Pg 936. ${ }^{\text {viii }}$

Brunetière effectively points out the same fundamental flaws - that Zola's results can only be fictional and biased by the original idea.

It is clear that Zola did apply a version of his method in his own work. The Rougon-Macquart cycle is a twenty novel series in which Zola attempts to study the genetic and social evolution of a family living in France under the Second Empire. In each novel, Zola attempted to study a particular social 'question'. For example, in L'Assomoir (1877), Zola attempts to study the alcoholism in the Parisian working classes. What exactly, however, his hypothesis, experiment or conclusions are from the novel are vague, undefined and do not reflect the kind of experiments Bernard would have considered to be scientific. In addition, Zola misquotes Bernard on key concepts and ultimately undermines the value of his own arguments by inconsistently attributing varying scientific values to the experimental novel.

\section{CONCLUSION}

Bernard outlined three stages to the experimental method: observation, experimentation, and conclusion. Zola's attempt to apply Bernard's method to the novel was theoretically flawed despite Zola's seeming understanding of the basic tenets of Bernard's arguments and method. While Zola had a sincere interest in science, his application of scientific theories in literature was convoluted, the specific hypotheses and results unclear, and ultimately, a far cry from scientifically accurate. Both authors set out with specific agendas, Bernard to prove that the future of medicine was as an experimental science, and Zola to prove that the future of literature was as an experimental science. Nearly two hundred years later, it is clear which of the two made better arguments. Zola failed to convince the audience of the present and of his time, but The Experimental Novel and Zola's body of work remains today a fascinating case study of the widespread influence of science in the nineteenth century and dynamic relationship between the arts and the sciences.

\section{ACKNOWLEDGMENTS}

I would like to extend a great big thank you to the Centre d'études du dix neuvième siècle français Joseph Sablé at the University of Toronto for their help in my research! I would particularly like to thank Professor Dorothy Speirs for being ever resourceful and wonderfully knowledgeable. Thanks to Professor Sofie Lachapelle from the University of Guelph's History department for her suggestions and comments. A big thank you goes out as well to my supervisor Professor Margot Irvine from the University of Guelph European Studies department for her suggestions, guidance, and patience!

\section{ENDNOTES}

i. Nous donnerons au mot expérience, en médecine expérimentale, le même sens général qu'il conserve partout. Le savant s'instruit chaque jour par l'expérience ; par elle il corrige incessamment ses idées scientifiques, ses théories, les rectifie pour les mettre en harmonie avec un nombre de faits de plus en plus grands, et pour approcher ainsi de plus en plus de la vérité. - Bernard. Introduction à l'étude de la médecine expérimentale.1865. Pg 21-22.

ii. Il est ainsi évident pour tout esprit non prévenu que la médecine se dirige vers sa voie scientifique définitive. Par la seule marche naturelle de son évolution, elle abandonne peu à peu la région des systèmes pour revêtir de plus en plus la forme analytique, et rentrer ainsi graduellement dans l'ode d'investigation commune aux sciences expérimentales. - Bernard. Introduction à l'étude de la médecine expérimentale.1865. Pg 7.

iii. Je vais tâcher de prouver à mon tour que, si la méthode expérimentale conduit à la connaissance de la vie physique, elle doit conduire aussi à la connaissance de la vie passionnelle et intellectuelle. Ce n'est là qu'une question de degrés dans la même 
voie, de la chimie à la physiologie, puis de la physiologie à l'anthropologie et à la sociologie. Le roman expérimental est au bout. - Zola. Le Roman Expérimental. Paris: Éditions du Sandre, 2003. Pg 10.

iv. ...arriver à la connaissance de la loi des phénomènes de manière à pouvoir prévoir, faire varier ou maîtriser ces phénomènes... - Bernard. Introduction à l'étude de la médecine expérimentale. 1865. Pg 30.

v. La simple constatation des faits ne pourra jamais parvenir à constituer une science. On aurait beau multiplier les faits ou les observations, que cela n'en apprendrait pas davantage. Pour s'instruire, il faut nécessairement raisonner sur ce que l'on a observé, comparer les faits et les juger par d'autres faits qui servent de contrôle. - Bernard. Introduction à l'étude de la médecine expérimentale. 1865. Pg 27.

vi. En effet, il y a dans toute connaissance expérimentale trois phases: observation faite, comparaison établie et jugement motivé. La méthode expérimentale ne fait pas autre chose que porter un jugement sur les faits qui nous entourent, à l'aide d'un critérium qui n'est lui-même qu'un autre fait disposé de façon à contrôler le jugement et à donner l'expérience. - Bernard. Introduction à l'étude de la médecine expérimentale. 1865. Pg 23.

vii. À la suite d'une observation, une idée relative à la cause du phénomène observé se présente à l'esprit ; puis on introduit cette idée anticipée dans un raisonnement en vertu duquel on fait des expériences pour la contrôler. - Bernard. Introduction à l'étude de la médecine expérimentale. 1865 . Pg 49-50.

viii. Dans la méthode expérimentale, la recherche des faits, c'est-à-dire l'investigation, s'accompagne toujours d'un raisonnement, de sorte que le plus ordinairement l'expérimentateur fait une expérience pour contrôler ou vérifier la valeur d'une idée expérimentale. - Bernard. Introduction à l'étude de la médecine expérimentale. 1865. Pg 32.

ix. L'expérimentateur doit alors disparaître ou plutôt se transformer instantanément en observateur; et ce n'est qu'après qu'il aura constaté les résultats de l'expérience $[. .$.$] que son esprit reviendra pour$ raisonner, comparer et juger si l'hypothèse expérimentale est vérifiée ou infirmée par ces mêmes résultats. - Bernard. Introduction à l'étude de la médecine expérimentale. 1865. 36.

x. expérience pour voir. - Bernard. Introduction à l'étude de la médecine expérimentale. 1865. Pg.33

xi. Je n'aurai à faire ici qu'un travail d'adaptation, car la méthode expérimentale a été établie avec une force et une clarté merveilleuse par Claude Bernard, dans son Introduction à la médicine expérimentale.
Ce livre [...] va me servir de base solide. [...] Ce ne sera donc qu'une compilation de textes; car je compte, sur tous les points, me retrancher derrière Claude Bernard. Le plus souvent, il me suffira de remplacer le mot «médecin" par le mot « romancier », pour rendre ma pensée claire et lui apporter la rigueur d'une vérité scientifique. - Zola. Le Roman Expérimental. Paris: Éditions du Sandre, 2003. Pg 9.

xii. ...Et, puisque des savants comme Claude Bernard démontrent maintenant que des lois fixes régissent le corps humain, on peut annoncer, sans crainte de se tromper, l'heure où les lois de la pensée et des passions seront formulées à leur tour. Un même déterminisme doit régir la pierre des chemins et le cerveau de l'homme. - Zola. Le Roman Expérimental. Paris: Éditions du Sandre, 2003. Pg 23.

xiii. Puis, l'expérimentateur paraît et institue l'expérience, je veux dire fait mouvoir les personnages dans une histoire particulière, pour $\mathrm{y}$ montrer que la succession des faits y sera telle que l'exige le déterminisme des phénomènes mis à l'étude. - Zola. Le Roman Expérimental. Paris: Éditions du Sandre, 2003. Pg 15.

xiv. Il est parti du doute pour arriver à la connaissance absolue; et il ne cesse de douter que lorsque le mécanisme de la passion, démontée et remontée par lui, fonctionne selon les lois fixées par la nature. Il n`y a pas de besogne plus large ni plus libre pour l'esprit humain. - Zola. Le Roman Expérimental. Paris: Éditions du Sandre, 2003. Pg 19.

xv. Souvent j'ai dit que nous n'avions pas à tirer une conclusion de nos œuvres, et cela signifie que nos œuvres portent leur conclusion en elles. Un expérimentateur n'a pas à conclure, parce que, justement, l'expérience conclut pour lui. [...] c'est à la société de produire toujours ou de ne plus produire ce phénomène, si le résultat en est utile ou dangereux. - Zola. Le Roman Expérimental. Paris: Éditions du Sandre, 2003. Pg 35.

xvi. La philosophie, en agitant sans cesse la masse inépuisable des questions non résolues, stimule et entretient ce mouvement salutaire dans les sciences. [...] L'indéterminé seul lui appartient, le déterminé retombant nécessairement dans le domaine scientifique. - Bernard. Introduction à l'étude de la médecine expérimentale. 1865. Pg 309-310.

xvii. L'esprit n'a en lui-même que le sentiment d'une relation nécessaire dans les choses, mais il ne peut connaître la forme de cette relation que par l'expérience. - Bernard. Introduction à l'étude de la médecine expérimentale. 1865. Pg 22. 
xviii. Il est évident que M. Zola ne sait pas ce que c'est expérimenter, car le romancier comme le poète, s’il expérimente, ne peut expérimenter que sur soi, nullement sur les autres [...] Il n'y a pas autrement ni ne peut y avoir d'expérimentation, il n’y a qu'observation, et dès là c'est assez pour que la théorie de M. Zola sur Le Roman expérimental manque, et croule aussitôt par la base. - Brunetière. Le Revue des deux mondes. 15 février 1880. Pg 936.

\section{REFERENCES}

1. Bernard, Claude. Introduction to the Study of Experimental Medicine. New York: Dover Publications,1957. Pg xv.

2. Ede, Andrew and Lesley Cormack. A History of Science in Society. Toronto: Broadview Press, 2004. Pg 276.

3. Bernard. Introduction to the Study of Experimental Medicine. 1957. Pg 28.

4. Bernard. Introduction to the Study of Experimental Medicine. 1957. Pg 43.

5. Bernard. Introduction to the Study of Experimental Medicine. 1957. Pg 201.

6. Charvet, P.E. A Literary History of France. Vol V. London: Ernest Benn Limited, 1967. Pg 20.

7. Pagès, Alain and Owen Morgan. Guide Emile Zola. Paris: Ellipses Édition Marketing, 2002. Pg.56-57.
8. Zola, Emile. "The Experimental Novel". The Naturalist Novel. Maxwell Geismar, ed. Ste. Anne de Bellevue: Harvest House Ltd., 1964. Pg 3.

9. Charvet. A Literary History of France. Vol V. 1967. Pg 21.

10. Bernard. Introduction to the Study of Experimental Medicine. 1957. Pg 18.

11. Bernard. Introduction to the Study of Experimental Medicine. 1957. Pg 6.

12. Bernard, Claude. Introduction à l'étude de la médecine expérimentale. 1865. Electronic publication based on the Paris: Baillère et fils, 1965 edition. http://www.gutenberg.org/etext/16234. Pg 33.

13. Bernard. Introduction à l'étude de la médecine expérimentale. 1865. Pg 13.

14. Bernard. Introduction to the Study of Experimental Medicine. 1957. Pg 21

15. Zola. The Experimental Novel. 1964. Pg 5.

16. Zola. The Experimental Novel. 1964. Pg 7.

17. Bernard. Introduction to the Study of Experimental Medicine. 1957. Pg 25.

18. Zola. The Experimental Novel. 1964. Pg 7.

19. Zola. The Experimental Novel. 1964. Pg 5.

20. Bernard, Introduction to the Study of Experimental Medicine. 1957. Pg 12 -13.

21. Translation by Pascale Rabideau. February 23, 2010. 